\title{
TOTAL PHENOLICS, ANTIOXIDANT AND ANTIMICROBIAL ACTIVITIES OF DALMATIAN LABURNUM (PETTERIA RAMENTACEA (SIEBER) C. PRESL) METHANOL EXTRACTS
}

Ukupni fenoli, antioksidativne i antimikrobne aktivnosti metanolnih ekstrakata tilovine (Petteria ramentacea (Sieber) C. Presl)

Fatima Pustahija ${ }^{1}$, Neđad Bašić ${ }^{1}$, Mirel Subašić ${ }^{1}$, Emira Hukić ${ }^{1}$, Mirsada Starčevic ${ }^{1}$, Rasim Duraković $^{2}$, Nađa Sinanović ${ }^{3}$, Jelena Knežević ${ }^{1}$, Erna Karalija ${ }^{4}$, Adisa Parić ${ }^{4}$

\begin{abstract}
The aim of this study was to determine the total concentrations of some phenolic compounds and antioxidant and antimicrobial activity of methanol extracts of different parts of Illyrian endemic Petteria ramentacea. Concentrations of phenolic compounds were determined with UV/VIS spectrophotometry. The antioxidant activity of plant extracts was determined by 2,2-diphenyl-1-picrylhydrazyl (DPPH) radical scavenging activity. Antimicrobial activity of extracts was evaluated by measuring the inhibition's zone against six selected test bacteria and two fungi. The highest average total phenols concentrations were in seeds (10.78 $\left.\mathrm{mg} \mathrm{GAE} \mathrm{g}^{-1} \mathrm{DW}\right)$, root (10.51 $\left.\mathrm{mg} \mathrm{GAE} \mathrm{g}^{-1} \mathrm{DW}\right)$ and bark (10.40 $\left.\mathrm{mg} \mathrm{GAE} \mathrm{g}^{-1} \mathrm{DW}\right)$, and the lowest in inflorescences (2.99 $\mathrm{mg} \mathrm{GAE} \mathrm{g}^{-1}$ $\mathrm{DW})$ and leaves (3.12 $\left.\mathrm{mg} \mathrm{GAE} \mathrm{g} \mathrm{g}^{-1} \mathrm{DW}\right)$. The total flavonoids concentrations were determined only in leaves (8.25 mg CE g $\left.{ }^{-1} \mathrm{DW}\right)$ and in stem (5.66 $\left.\mathrm{mg} \mathrm{CE} \mathrm{g}^{-1} \mathrm{DW}\right)$. Both flavanols and proanthocyanidins $\left(0.75 \mathrm{mg} \mathrm{CE} \mathrm{g}^{-1} \mathrm{DW}\right.$ and $3.49 \mathrm{mg} \mathrm{CE} \mathrm{g}^{-1} \mathrm{DW}$, respectively) were found only in leaves. Analysis of variance indicated presence of significant differences between total phenols and flavanols concentrations $(p<0.05)$, and Duncan's test confirmed the presence of intraspecies variability according to their concentrations. The highest antioxidant activity $\left(\mathrm{IC}_{50}\right)$ was observed for the seed's extract $(6.86 \%)$ and the lowest for the bark's $(51.31 \%)$. All methanol extracts showed the most pronounced antibacterial activity against Staphylococcus epidermididis, and the lowest against $S$. aureus subsp. aureus. Antifungal activity against Candida albicans was moderate. Since Peteria ramentacea methanol extracts are potential natural antioxidant and antimicrobial preparations against selected microorganisms, it is necessary to continue with more detailed analysis.
\end{abstract}

Key words: antibacterial, antifungal, Balkan endemic, Fabaceae, phenolic compounds

\footnotetext{
${ }^{1}$ Faculty of Forestry, University of Sarajevo, Bosnia and Herzegovina

${ }^{2}$ Sarajevska bb, 77245 Bužim, Bosnia and Herzegovina

${ }^{3}$ UNDP, Zmaja od Bosne bb, 71000 Sarajevo, Bosnia and Herzegovina

${ }^{4}$ Faculty of Sciences, University of Sarajevo, 71000 Sarajevo, Bosnia and Herzegovina
} 


\section{INTRODUCTION - Uvod}

Plants have an ability to synthesize different bioactive organic compounds with antioxidant, antimicrobial and anti-inflammatory properties. Among them, phenolics and phenolic-related compounds are very interesting for humans in medicine, pharmacology, and food processing and cosmetics industry since they can reduce oxidative stress (CROZIER et al. 2006, VERMERRIS and NICHOLSON 2008). According this, there is growing interest in the identification, valorisation and using of plant extracts which show different bioactive properties.

Dalmatian laburnum (Petteria ramentacea (Sieber) C. Presl, Fabaceae) is deciduous, erect, medium-sized and fairly branched, the Illyrian-Balkan endemic shrub in the Balkan sub-Mediterranean area. It spread from Central Dalmatia, across Bosnia and Herzegovina, Montenegro and Albania to northern Greece. It is valuable melliferous species suitable, also, for preventing soil erosion and as for feeding livestock (FUKAREK 1949, NADAŽDIN and ĆURIĆ 1966).

Total content of phenols, flavonoids, flavanols and proanthocyanidins in methanol extracts of different parts (leaves, inflorescences, stem, bark, root and seeds) of Dalmatian laburnum is determined in this study. The antioxidant activity of plant extracts was determined as the free radical scavenging ability, while antimicrobial activity was evaluated by measuring the inhibition's zone against selected eight test microorganisms.

\section{MATERIAL AND METHODS - Materijal i metode}

\section{Plant material - Biljni materijal}

Plant material (leaves, inflorescences, stem, bark, root and seeds) was collected from healthy P. ramentacea individuals in its natural population during April and July 2017. Material was collected from ten shoots on seven individuals. Separation of plant material was carried out immediately and packed into paper bags. In the laboratory, the plant material was washed with running tap water, rinsed with distilled water and dried during 48 hours at $50-60^{\circ} \mathrm{C}$. Finally, dried materials were grounded into powder by mixer and stored in plastic bags until extraction processes. Voucher specimens have been deposited in the herbarium of the Faculty of Forestry, University of Sarajevo.

\section{Plant habitat - Stanište}

The study was made within the natural Dalmatian laburnum habitat which is located in Diva Grabovica, 16 km south-west from Jablanica ( $43^{\circ} 35^{\prime} 161^{\prime \prime} \mathrm{N}, 17^{\circ} 43^{\prime}$ 048" W). Here, the Dalmatian laburnum is found in its typical environment of degraded oak forests in altitude range between 224-231 m ASL, exposed to south and south-west. Broader area was characterized with long steep $\left(25-30^{\circ}\right)$, rocky slopes (75-85\%), occasional fluvial-glacial depositions and grindstones (Figure 1). Soil types were translated into the international WRB system (IUSS WORKING GROUP WRB 2007). According to the Basic soil map of Bosnia and Herzegovina (FZAP 2013) a 
predominant soil is complex unit of Leptosol, Rendzic Leptosol, Cambisol and Coluvisol on Triassic Limestone characterized as mainly shallow, rocky, skeletal with low productivity. Soils with lithic contact show lower productivity and water holding capacity compared to loose calcareous deposits.
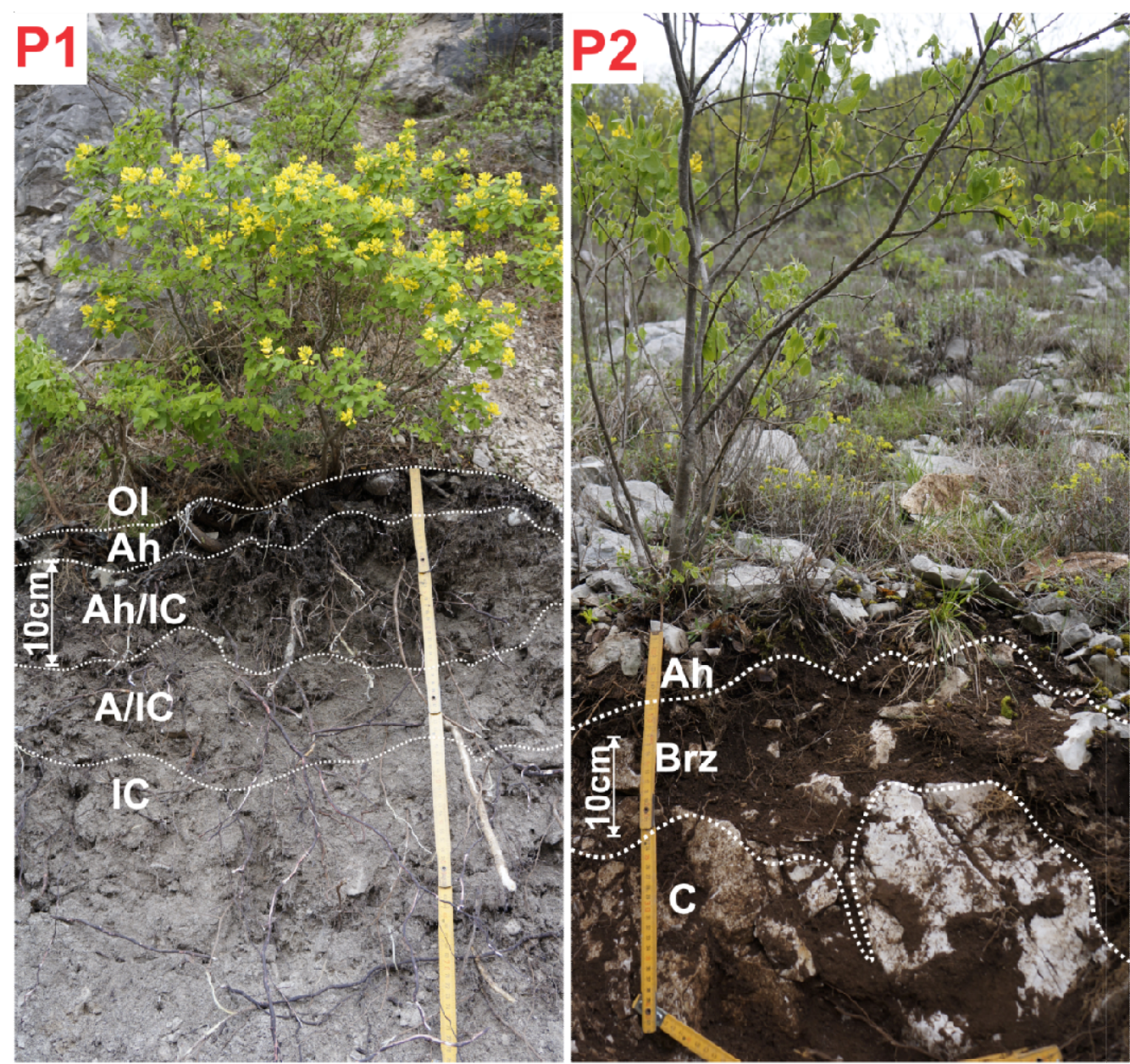

Figure 1. Dalmatian laburnum habitat: individuals on Rendzic Leptosol (P1) and on Leptic Cambisol Chromic (P2) in Diva Grabovica.

Slika 1. Stanište tilovine: individua na rendzini (P1) $i$ na kalkokambisolu (P2) u Divi Grabovici.

Characteristics of rhizosphere soil (Table 1) were described and analysed with an explanatory objective to address possible differences in chemical characteristics of plant material. The root density and distribution were determined by soil hydrophysical and chemical properties. Variability of soil conditions most importantly in 

ramentacea (Sieber) c. Presl) methanol extracts

water and nutrients supply is illustrated by root distribution. Based on survey data most roots in Rendzic Leptosol (P1) are found as more uniformly distributed through the profile, while in Leptic Cambisol Chromic (P2) they were distributed across soil surface. Soils did not exceed $40 \mathrm{~cm}$ of depth. They had sandy to sandy loam texture, high gravel content which indicated low water holding capacity. Structure was described as granular to single grained in profile P1 and granular to blocky in P2. Chemical characteristics were determined by high carbonate content $\left(\mathrm{CaCO}_{3}\right)$, neutral to alkali reaction and variable concentrations of soil organic carbon (SOC).

Table 1. Characteristics of rhizosphere soil of collected individuals of Petteria ramentacea Tabela 1. Karakteristike tla rizosfere sakupljenih individua Petteria ramentacea

\begin{tabular}{|c|c|c|c|c|c|c|c|c|c|c|c|}
\hline $\begin{array}{l}\text { Profile } \\
\text { No }\end{array}$ & Horizont & $\begin{array}{l}\text { Depth } \\
\text { (cm) }\end{array}$ & Color $^{1}$ & Texture $^{2}$ & $\begin{array}{c}\text { Gravel }^{2} \\
(\%)\end{array}$ & $\begin{array}{l}\text { Structure } \\
\text { type }^{2}\end{array}$ & $\begin{array}{c}\text { Roots }^{2} \\
\text { No/dm }\end{array}$ & $\mathrm{pH}_{\mathrm{H} 2 \mathrm{O}^{3}}$ & $\mathbf{p H}_{\mathrm{CaCl}^{3}}{ }^{3}$ & $\begin{array}{c}\mathrm{SOC}^{4} \\
(\%)\end{array}$ & $\begin{array}{c}\mathrm{CaCO}_{3}{ }^{5} \\
(\%)\end{array}$ \\
\hline \multicolumn{12}{|c|}{ P1: Reudzic Leptosol } \\
\hline & OI & $\begin{array}{c}+4.5- \\
0.0\end{array}$ & - & - & - & - & - & - & - & - & - \\
\hline & $\mathrm{Ah}$ & $\begin{array}{l}0.0- \\
8.0\end{array}$ & $10 \mathrm{YR} 4 / 2$ & Sand & $30-35 \%$ & Granular & 32.5 & 6.57 & 7.06 & 2.50 & 5.5 \\
\hline & $\mathrm{Ah} / \mathrm{IC}$ & $8.0-20$ & $10 \mathrm{YR} 5 / 3$ & Sand & $40-50 \%$ & $\begin{array}{l}\text { Sing. } \\
\text { grained }\end{array}$ & 24.5 & 6.57 & 7.06 & 0.83 & $>50 \%$ \\
\hline & $\mathrm{A} / \mathrm{IC}$ & $20-40$ & $10 \mathrm{YR} 5 / 3$ & Sand & $40-50 \%$ & $\begin{array}{l}\text { Sing. } \\
\text { grained }\end{array}$ & 24.5 & 6.88 & 7.07 & 0.61 & $>50 \%$ \\
\hline & IC & $>40$ & $10 \mathrm{YR} 5 / 3$ & Sand & $40-50 \%$ & $\begin{array}{l}\text { Sing. } \\
\text { grained }\end{array}$ & 24.5 & 7.01 & 7.07 & 0.42 & $>50 \%$ \\
\hline \multicolumn{12}{|c|}{ P2: Leptic Cambisol Chromic } \\
\hline & $\mathrm{Ah}$ & $\begin{array}{l}0.0- \\
6.0\end{array}$ & $5 Y R 3 / 2$ & $\begin{array}{l}\text { Sandy } \\
\text { Loam }\end{array}$ & $35-40 \%$ & Granular & 57 & 6.95 & 7.02 & 9.94 & 7.82 \\
\hline & $\mathrm{Brz}$ & $6.0-50$ & $5 Y R 3 / 2$ & $\begin{array}{l}\text { Sandy } \\
\text { Loam }\end{array}$ & $89-90 \%$ & Blocky & 18 & 7.15 & 7.05 & 7.40 & $>50 \%$ \\
\hline & $\mathrm{C}$ & $>50$ & - & $\begin{array}{l}\text { Sandy } \\
\text { Loam }\end{array}$ & - & & - & - & - & - & - \\
\hline
\end{tabular}

${ }^{1}$ Color according to MUNSELL COLOR (1994)

${ }^{2}$ Texture, gravel content, structure and number of roots were assessed in filed (FAO 2006)

${ }^{3} \mathrm{pH}_{\mathrm{H} 2 \mathrm{O}}$ and $\mathrm{pH}_{\mathrm{CaCl} 2}$ values determined in water and $0.01 M \mathrm{CaCl}_{2}$ dilution, respectively, by using pH-meter (ISO10390 2005)

${ }^{4}$ SOC - soil organic carbon concentration was determined by dichromate method (WALKLEY AND BLACK 1934) by spectrophotometry

${ }^{5} \mathrm{CaCO}_{3}-\mathrm{CaCO}_{3}$ concentration was determined volumetrically by Eijkelkamp Calcimeter (ISO 10693 1994).

\section{Chemicals and reagents - Hemikalije $i$ reagensi}

Gallic acid, catechin and DPPH are HPLC purity, and other used chemicals and solvents were of analytical grade purchased from Sigma-Aldrich (Steinheim, Germany). 


\section{Methanol extracts preparation - Pripremanje metanolnih ekstrakata}

Different powdered dry samples $(0.4 \mathrm{~g})$ were extracted with $80 \%$ aqueous methanol $(2 \times 12 \mathrm{~mL})$ in an ultrasonic bath (Elmasonic $\mathrm{S} 60 \mathrm{H})$ for 30 minutes. Extracts were then centrifuged at 2,300 rpm for 15 minutes (Centric $322 \mathrm{~B}$, Techtnica). Obtained supernatants were combined, filtrated and volume of the extract was adjusted with extraction mixture up to $25 \mathrm{~mL}$, and stored in plastic tubes at $-20^{\circ} \mathrm{C}$ for further analysis. The Shimadzu UV-mini 1240 spectrophotometer was used for determination of phenolic contents and antioxidant activity of all methanol extracts. All values are presented as means of triplicate analyses.

\section{Determination of total phenols - Odredivanje ukupnih fenola}

Total phenolic content was determined using modified Folin-Ciocalteu method (WOLFE et al. 2003). Diluted methanol sample was mixed with $100 \mu \mathrm{L}$ of Folin-Ciocalteu's reagent and $300 \mu \mathrm{L}$ of freshly prepared sodium carbonate solution (7.5\%). After mixing, the samples were incubated for 30 minutes at $45^{\circ} \mathrm{C}$ in water bath until blue color development. Blank was prepared by using $80 \%$ methanol instead of sample. The absorbance of the coloured solvents was measured at $765 \mathrm{~nm}$ against the blank, and calibration curve was prepared with gallic acid as a standard. Total phenolic content was expressed as mg of gallic acid equivalents per gram of dry plant sample (mg GAE $\left.\mathrm{g}^{-1}\right)$.

\section{Determination of total flavonoids - Određivanje ukupnih flavonoida}

Determination of total flavonoid content was done using modified method of ORDOÑEZ et al. (2006). Diluted methanol extract aliquots were mixed with $105 \mu \mathrm{L}$ of distilled water, $25 \mu \mathrm{L}$ of $10 \%$ aluminium chloride water solution and $25 \mu \mathrm{L}$ of $1 \mathrm{M}$ sodium acetate water solution, followed by the addition of $700 \mu \mathrm{L}$ of distilled water and $375 \mu \mathrm{L} 96 \%$ of methanol. The mixture was left for homogenization and incubation at room temperature for 20 minutes. The absorbance of coloured samples was measured at $415 \mathrm{~nm}$ against the blank. Total flavonoid content was expressed as $\mathrm{mg}$ of catechin equivalent per gram of dry sample ( $\left.\mathrm{mg} \mathrm{CE} \mathrm{g}^{-1}\right)$.

\section{Determination of total flavanols - Odredivanje ukupnih flavanola}

Quantification of total flavanols was carried out using modified GADZOVSKA et al. (2007) method. Per $1000 \mu \mathrm{L}$ of $0.1 \%$ DMACA reagent (p-(Dimethylamino) cinnamaldehyde) is added to all analysed methanol samples $(200 \mu \mathrm{L})$. After the mixtures were incubated for 10 minutes at room temperature, absorbance was measured at $640 \mathrm{~nm}$ against the blank. The results were expressed as catechin equivalents per gram of dry sample ( $\left.\mathrm{mg} \mathrm{CE} \mathrm{g}^{-1}\right)$. 


\section{Determination of total proanthocyanidins - Određivanje ukupnih proantocijanidina}

Total proanthocyanidins content was measured by modified method of WETTSTEIN et al. (1977). An aliquot of methanol extract $(50 \mu \mathrm{L})$ was mixed with 750 $\mu \mathrm{L}$ of $4 \%$ vanillin-methanol solution and $375 \mu \mathrm{L}$ of hydrochloric acid. The tubes were vortexed and the absorbance was immediately measured at $500 \mathrm{~nm}$. Total proanthocyanidins content was expressed as $\mathrm{mg}$ of catechin equivalent per gram of dry weight ( $\mathrm{mg} \mathrm{CE} \mathrm{g}^{-1}$ ).

\section{Determination of antioxidant activity by DPPH method - Odredivanje antioksidativne aktivnosti DPPH metodom}

The antioxidant activity of the methanol extracts was assessed by DPPH free radical scavenging modified method by MEDA et al. (2005). Aliquots of diluted methanol extracts were mixed with freshly prepared ethanol DPPH solution and incubated for 30 minutes at room temperature in the dark. The absorbance of the solutions was measured at $515 \mathrm{~nm}$ against $96 \%$ ethanol as a blank.

The ability to scavenge the DPPH radical was calculated as follows: DPPH scavenging effect $(\%)=\left[\left(\mathrm{A}_{\mathrm{a}}-\mathrm{A}_{\mathrm{b}}\right) / \mathrm{A}_{\mathrm{a}}\right] \times 100$; in which $\mathrm{A}_{\mathrm{a}}$ is the absorbance of DPPH blank, and $\mathrm{A}_{\mathrm{b}}$ is the absorbance of DPPH with sample in different concentrations. The antioxidant activity was expressed as half maximal inhibition concentration $\left(\mathrm{IC}_{50}\right)$, calculated graphically based on the calibration curves for each sample. The lower $\mathrm{IC}_{50}$ values indicated the higher antioxidant activity in the methanol extracts.

\section{Estimation of antimicrobial activity - Procjena antimikrobne aktivnosti}

Standard disc diffusion method (BAUER ET AL. 1966) was used to test the antimicrobial activity of methanol extracts against gram positive (Bacillus subtilis subsp. spizizenii $\mathrm{ATCC}^{\circledR} 6633^{\mathrm{TM}}$, Staphylococcus aureus subsp. aureus ATCC $^{\circledR}$ $6538^{\mathrm{TM}}$ and Staphylococcus epidermididis $\mathrm{ATCC}^{\circledR} 8739^{\mathrm{TM}}$ ) and gram negative (Escherichia coli ATCC ${ }^{\mathbb{B}} 8739^{\mathrm{TM}}$, Pseudomonas aeruginosa $\mathrm{ATCC}^{\mathbb{B}} 9027^{\mathrm{TM}}$ and Salmonella abony $\mathrm{NCTC}^{\circledR} 6017^{\mathrm{TM}}$ ) bacteria, and two fungi Aspergillus brasiliensis $\mathrm{ATCC}^{\circledR} 16404^{\mathrm{TM}}$ and Candida albicans $\mathrm{ATCC}^{\circledR} 10231^{\mathrm{TM}}$.

Petri dishes with sterile Müeller Hinton and Sabouraud dextrose agars were inoculated with $1 \mathrm{~mL}$ of bacterial and fungal suspension, respectively. Then, sterile discs, $6 \mathrm{~mm}$ in diameter (Whatman Antibiotic Assay Discs), impregnated with $25 \mu \mathrm{L}$ of methanol extracts were placed on the inoculated agars. Standard discs of Amoxicillin (Amx10mcg) and Nystatin $(10.000 \mathrm{U} / \mathrm{mL})$ served as positive antibiotic controls, while disc with $80 \%$ methanol was used as blank control. The treated plates with discs were incubated at $37^{\circ} \mathrm{C}$ for 24 hours after which antibacterial activity was assessed by measuring the zone of growth inhibition around the discs. 


\section{Statistical analysis - Statistička analiza}

Obtained data were performed with the SPSS statistical software program (IBM SPSS statistics 20, USA). Means were expressed with their standard errors and compared by one-way analysis of variance (ANOVA). To determine the significant differences between groups, after analysis of variance, Duncan's post-hoc test was used at $\mathrm{p}<0.05$.

\section{RESULTS AND DISCUSSION - Rezultati i diskusija}

\section{Phenolic compounds - Fenolna jedinjenja}

Plants produce secondary metabolites, most commonly, against pathogenic attacks and environmental stresses (YANG et al. 2018). Thereby, the plant pharmacological characteristics reflect its phenolic composition, which varies significantly depending on the genotype, phenophase and ecological conditions (KÄHKÖNEN et al. 1999, ZHENG and WANG 2001, SPIRIDON et al. 2011).

The activity of natural plant extracts depends on the present compounds, their interdependencies, type and polarity of organic solvents for extraction and isolation (ZHENG and WANG 2001, OREOPOULOU, 2003). Although, according to literary sources, the methanol extracts contain the highest content of total phenolic compounds in comparison to other types of solvents (AO et al. 2008, and references therein), the complete quantitative and qualitative representation of total phenolic compounds in plant extracts can not be obtained using the Folin-Ciocalteu method due to possible presence of certain nonpolyphenol-derived compounds (sugars, aromatic amines, $\mathrm{SO}_{2}$, vitamin C, organic acids etc.; KÄHKÖNEN et al. 1999, SINGELTON et al. 1999).

Species in the family Fabaceae possess' unique and specific chemical composition characterized with very variable phenolic compounds, especially flavonoids. Most of the chemical compounds within this family have defensive functions or act as signalling molecules, whereby some genera/species are very rich in various structural types of metabolites whose concentrations vary considerably in different plant parts, seasonally but also in relation to environmental conditions (MADRID et al. 2012, NAGHILOO et al. 2012, PEREIRA et al. 2012, WINK, 2013).

Results presented in this study for polyphenolic compounds are reported for the first time for the given species (Table 2). The presence of phenols was confirmed in all six analysed plant parts of the Dalmatian laburnum, while flavonoids were detected only in leaves and stem, and flavanols and proanthocyanidins in leaves. The highest average recorded total phenols were in seeds $\left(10.78 \mathrm{mg} \mathrm{GAE} \mathrm{g}^{-1} \mathrm{DW}\right)$, root (10.51 $\left.\mathrm{mg} \mathrm{GAE} \mathrm{g}^{-1} \mathrm{DW}\right)$ and bark (10.40 mg GAE $\left.\mathrm{g}^{-1} \mathrm{DW}\right)$, and the lowest in inflorescences (2.99 $\left.\mathrm{mg} \mathrm{GAE} \mathrm{g}^{-1} \mathrm{DW}\right)$ and leaves $\left(3.12 \mathrm{mg} \mathrm{GAE} \mathrm{g}^{-1} \mathrm{DW}\right)$. The flavonoids were recorded in leaves $\left(8.25 \mathrm{mg} \mathrm{CE} \mathrm{g}^{-1} \mathrm{DW}\right)$ and stem $\left(5.66 \mathrm{mg} \mathrm{CE} \mathrm{g}^{-1}\right.$ $\mathrm{DW})$. Flavanols and proanthocyanidins $\left(0.75 \mathrm{mg} \mathrm{CE} \mathrm{g}^{-1} \mathrm{DW}\right.$ and $3.49 \mathrm{mg} \mathrm{CE} \mathrm{g}^{-1} \mathrm{DW}$, respectively) were found in leaves. 
Total phenolics, antioxidant and antimicrobial activities of Dalmatian laburnum (Petteria ramentacea (Sieber) c. Presl) methanol extracts

Table 2. Basical descriptive parameters of analyzed secondary metabolites for Petteria ramentacea (mg $\mathrm{g}^{-1} \mathrm{DW} ; \mathrm{X}$ - average, SD - standard deviation, $\mathrm{CV}$ - coefficient variation)

Tabela 2. Osnovni deskriptivni parametri analiziranih sekundarnih metabolita za vrstu Petteria ramentacea ( $\mathrm{mg} \mathrm{g}^{-1}$ suhe materije; $X$ - srednja vrijednost, $S D$ - standardna devijacija, $C V-$ koeficijent varijacije)

\begin{tabular}{|c|c|c|c|c|c|}
\hline $\begin{array}{l}\text { Plant } \\
\text { part }\end{array}$ & Parameters & Phenols $^{\mathrm{a}}$ & Flavonoids $^{b}$ & Flavanols $^{\text {b }}$ & Proanthocyanidins ${ }^{b}$ \\
\hline \multirow{5}{*}{$\stackrel{0}{0}$} & Min & 2.559 & 7.751 & 0.615 & 3.314 \\
\hline & Max & 3.411 & 8.966 & 0.866 & 3.661 \\
\hline & $\mathrm{X}$ & 3.119 & 8.245 & 0.745 & 3.493 \\
\hline & SD & 0.326 & 0.448 & 0.092 & 0.122 \\
\hline & $\mathrm{CV}(\%)$ & 10.466 & 5.437 & 12.368 & 3.480 \\
\hline \multirow{5}{*}{$\frac{\Xi}{\stackrel{D}{D}}$} & Min & 4.542 & 5.063 & & \\
\hline & Max & 6.119 & 6.454 & & \\
\hline & $\mathrm{X}$ & 5.246 & 5.657 & & \\
\hline & SD & 0.562 & 0.578 & & \\
\hline & CV (\%) & 10.709 & 10.223 & & \\
\hline \multirow{5}{*}{$\begin{array}{l}\text { 范 } \\
\ddot{ص}\end{array}$} & Min & 8.368 & & & \\
\hline & Max & 11.873 & & & \\
\hline & $\mathrm{X}$ & 10.400 & & & \\
\hline & SD & 1.294 & & & \\
\hline & CV (\%) & 12.443 & & & \\
\hline \multirow{5}{*}{$\begin{array}{l}\overrightarrow{0} \\
\stackrel{2}{2}\end{array}$} & Min & 9.225 & & & \\
\hline & Max & 11.866 & & & \\
\hline & $\mathrm{X}$ & 10.507 & & & \\
\hline & SD & 1.067 & & & \\
\hline & $\mathrm{CV}(\%)$ & 10.159 & & & \\
\hline \multirow{5}{*}{ 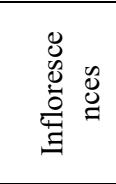 } & Min & 2.454 & & & \\
\hline & Max & 3.655 & & & \\
\hline & $\mathrm{X}$ & 2.995 & & & \\
\hline & SD & 0.480 & & & \\
\hline & CV (\%) & 16.021 & & & \\
\hline \multirow{5}{*}{$\begin{array}{l}\text { D } \\
\mathbb{D} \\
\tilde{W}\end{array}$} & Min & 9.065 & & & \\
\hline & Max & 12.905 & & & \\
\hline & $\mathrm{X}$ & 10.784 & & & \\
\hline & SD & 1.574 & & & \\
\hline & CV (\%) & 14.594 & & & \\
\hline
\end{tabular}

Note: $\mathrm{a}$ - expressed as $\mathrm{mg} \mathrm{g}^{-1} \mathrm{GA}$ (gallic acid), $\mathrm{b}$ - expressed as $\mathrm{mg} \mathrm{g}^{-1} \mathrm{C}$ (catechin)

Since genus Petteria is monospecific, its phenolic composition was compared with the phylogenetically closest relatives previously investigated: Cytisus scoparius, C. multiflorus, Genista quadriflora, G. vuralii, G. sandrasica, Glycyrrhiza glabra, Lupinus angustifolius, L. polyphyllus and Spartium junceum. These species were evaluated as potential sources of phenols with antioxidant activity, with some nonflavonoid phenolics as well as bioactive compounds (WOYDIŁO et al. 2007, LUIS et al. 2009, ORHAN et al. 2010, PEREIRA et al. 2012, ZHAO, 2014).

According to literature data, in the methanol extracts of leaves of the Fabaceae family members, the amount of total phenols varies considerably, which greatly depends on the intensity of the sun's radiation (MADRID et al. 2012, NAGHILOO et al. 
2012). According to the results obtained in this study, Dalmatian laburnum has relatively low and moderate values of the total phenols, especially in bark, root and seeds, which coincide with the allegations of some authors about their variability within the plant (KÄHKÖNEN et al. 1999, ZHENG and WANG 2001, SPIRIDON et al. 2011).

Flavanols are biologically active molecules of strong antioxidant activity, which biological effects depend very much on their bioavailability (FERNANDES et al. 2012, and references therein). Although isoflavones are characteristic for Fabaceae (ABOU-ZAID and SCOTT 2012) there is no data in available literature on total flavanols so the results obtained in this study are very interesting (Table 2).

Although proanthocyanidins are not specific for leguminous plants they are very important their constituents (AOKI et al. 2000, and references therein). By investigating the chemical composition of some leguminous plants with protective function in plants, antioxidative and medicinal properties, the presence of a large number of proanthocyanidins was observed but in relatively small amounts (TALA et al. 2013). The values of total proanthocyanidins in the leaves of $P$. ramentacea are low to moderate and approximately the same as the values of total phenols (Table 2).

Flavonoids play key role in adapting of legume individuals to its environmental conditions either as defence compounds (phytoalexins) or as chemical signals in symbiotic fixation of atmospheric nitrogen with Rhizobium bacteria. Many of identified flavonoids of taxa from related genera of $P$. ramentacea have antioxidative, insecticidal, cytotoxic and antifungal activity (OOMAH et al. 2006, WOYDItO et al. 2007, LUIS et al. 2009, ORHAN et al. 2010, ZHAO, 2014). The obtained values of total flavonoids in the leaves and stem of the $P$. ramentacea (Table 2) are relatively low but within the published rank for the family. The obtained results are consistent with the claims of many authors that differences in the amount of total phenols depend mainly on the characteristics of species and their varieties, climatic changes, agrotechnical and storage conditions, and methods for extraction of the compounds (OOMAH et al. 2006, and references therein).

In this study, analysis of variance indicated presence of significant differences between total phenols and flavanols concentrations $(p<0.05)$, and Duncan's test confirmed the presence of intraspecies variability according to their concentrations. According to total phenols concentrations is possible to clearly distinguish leaves, stem and inflorescences compared to other plant parts, except in relation leavesinflorescences.

\section{Antioxidative activity of methanol extracts of Petteria ramentacea - Antioksidativna aktivnost metanolnih ekstrakata Petteria ramentacea}

Antioxidant activity of plant extracts depends on the active compounds present in them, their concentrations and synergies. A large number of authors (KÄHKÖNEN et al. 1999, ROBARDS et al. 1999, SANCHEZ-MORENO et al. 1999, ZHENG and WANG 2001, SPIRIDON et al. 2011) consider that the antioxidant activity 
of plant extracts is in significant correlation with the presence of different groups of phenolic compounds, especially phenols and flavonoids.

However, the relationship between antioxidant activity and total phenols content in plant extracts is still a big unknown because both is often difficult to determine and characterize each phenolic compound in the extract and, often, the total phenols do not include all the antioxidants present in plant extracts (e.g. ascorbic acid, tocopherol, pigments and some minerals). Then, the antioxidant activity of the extracts depends on the concentration of the antioxidants and their structure and interaction (SANCHEZ-MORENO et al. 1999, SPIRIDON et al. 2011). Because of all this, a numerous authors (KÄHKÖNEN et al. 1999, SINGELTON et al. 1999, KAUR and MONDAL 2014) consider that the antioxidant activity of plant extracts can not be predicted based on their total phenolic content.

In this study, the antioxidant ability to "capture" free radicals, expressed as percent inhibition (AA), varies from 13.06 to $51.43 \%$ (Table 3). The highest antioxidant activity had methanol extracts of seeds and leaves $\left(\mathrm{IC}_{50}=6.86 \mathrm{mg} \mathrm{mL}^{-1}\right.$ and $19.86 \mathrm{mg} \mathrm{mL} \mathrm{m}^{-1}$, respectively). The antioxidative activity of other analysed Dalmatian laburnum extracts had quite uniform and moderate DPPH values. There was no correlation between the apparent concentrations of total phenols, flavonoids, flavanols and proanthocyanidins with antioxidant activity.

Table 3. The percentage inhibition of DPPH (AA\%), antioxidative activity $\left(\mathrm{IC}_{50} ; \mathrm{mg} \mathrm{mL}^{-1}\right)$, and antimicrobial activity (expressed as zone of inhibition) of methanol extracts of Petteria ramentacea against selected microbial strains (mean \pm ST.DEV., $\mathrm{n}=3$ )

Tabela 3. Procenat inhibicije DPPH (AA\%), antioksidativna aktivnost $\left(I_{50} ; m g L^{-1}\right)$ i antimikrobna aktivnost (izražena kao zona inhibicije) metanolnih ekstrakata Petteria ramentacea protiv odabranih mikrobnih sojeva (srednja vrijednost $\pm S T . D E V ., n=3$ )

\begin{tabular}{cccccccccc}
\hline & & \multicolumn{7}{c}{ The diameter of the inhibition zone including disk (5 mm) } \\
\cline { 4 - 10 } Extracts & \multirow{2}{*}{$\mathbf{A A}$} & \multirow{2}{*}{$\mathbf{I C}_{\mathbf{5 0}}$} & $\mathbf{A B}$ & $\mathbf{C A}$ & $\mathbf{B S}$ & $\mathbf{E C}$ & $\mathbf{2}$ PA & \multirow{2}{*}{ SAb } & \multirow{2}{*}{ SAu } \\
\cline { 4 - 11 } $\mathbf{N C}$ & & & 0 & 0 & 0 & 0 & 0 & 0 & 0 \\
\hline $\mathbf{P C}$ & & & $21 \pm 0.2$ & $20 \pm 0.2$ & $23 \pm 0.2$ & $20 \pm 0.2$ & $22 \pm 0.2$ & $23 \pm 0.3$ & $28 \pm 0.2$ \\
\hline $\mathbf{R}$ & 17.35 & 36.84 & $7.7 \pm 0.2$ & $8.1 \pm 0.15$ & $7.7 \pm 0.15$ & $8.1 \pm 0.1$ & $6.9 \pm 0.1$ & $8.5 \pm 0.15$ & $7.3 \pm 0.2$ \\
\hline $\mathbf{S}$ & 13.06 & 40.94 & $6.9 \pm 0.1$ & $6.5 \pm 0.15$ & $6.5 \pm 0.1$ & $6.5 \pm 0.15$ & $7.7 \pm 0.15$ & $8.1 \pm 0.1$ & $7.7 \pm 0.15$ \\
\hline $\mathbf{B}$ & 14.01 & 51.31 & 0.0 & $7.3 \pm 0.1$ & $10.0 \pm 0.2$ & $7.3 \pm 0.2$ & $6.9 \pm 0.1$ & $7.7 \pm 0.15$ & $6.2 \pm 0.15$ \\
\hline $\mathbf{L}$ & 27.22 & 19.86 & $6.9 \pm 0.15$ & $7.3 \pm 0.2$ & $6.5 \pm 0.15$ & $6.9 \pm 0.15$ & $6.2 \pm 0.15$ & $8.1 \pm 0.15$ & $7.7 \pm 0.1$ \\
\hline $\mathbf{I}$ & 15.98 & 48.10 & $6.9 \pm 0.2$ & $6.5 \pm 0.1$ & $6.9 \pm 0.15$ & $6.9 \pm 0.15$ & $6.9 \pm 0.1$ & $7.7 \pm 0.2$ & $6.9 \pm 0.2$ \\
\hline $\mathbf{S}$ & 51.43 & 6.86 & $6.5 \pm 0.15$ & $7.7 \pm 0.15$ & $7.7 \pm 0.2$ & $7.3 \pm 0.1$ & $7.7 \pm 0.15$ & $8.5 \pm 0.1$ & $7.7 \pm 0.15$ \\
\hline
\end{tabular}

Note: NC - negative control; PC - positive control; $\mathbf{R}$ - root; $\mathbf{S}$ - stem; $\mathbf{B}$ - bark; L - leaf; I inflorescence; $\mathbf{S}$ - seeds; AB - Aspergillus brasiliensis; CA - Candida albicans; BS - Bacillus subtilis subsp. spizizenii; EC - Escherichia coli; PA - Pseudomonas aeruginosa; SAb - Salmonella abony; SAu - Staphylococcus aureus subsp. aureus.

PEREIRA et al. (2012), ZHAO, (2014) and AIT-KACIAOURAHOUN et al. (2015) concluded that the various extracts of some Cytisus species possess antioxidant activity that depends on the plant material and the extraction method. PEREIRA et al. (2012) and AIT-KACIAOURAHOUN et al. (2015) suggest that phenols are responsible 
for antioxidant properties of some Cytisus, while ZHAO, (2014) states that at $C$. scoparius alkaloids are responsible for many of its biological activities, particularly antioxidant.

HANGANU et al. (2016) found a correlation between the total content of phenols and flavonoids with antioxidativity of Genista tinctoria extracts. But, there are contradictory data on the correlation between the phenols content and the antioxidant properties of $G$. saharae which are most likely due to the application of different solvents during extraction (BOUCHOUKA et al. 2012, GUETTAF et al. 2016).

Glycyrrhiza glabra root extract has a very pronounced antioxidant activity (HERAVI et al. 2013, ASAN-OZUSAGLAM and KARAKOCA 2014), which is significantly enhanced when mixed with Cotoneaster medicus extract (HERAVI et al. 2013), indicating the need for additional research into the isolation of active compounds and their synergism. WANG and CLEMENTS, (2008) found that antioxidant activity of 11 Lupinus taxa was significantly different depending on the species and varieties and that there was no correlation between antioxidant activity and total phenols content, while ZHAO, (2014, and references therein) states that the antioxidative activity of Spartium junceum depends on the content of flavonoids, flavonoid glycosides and other phenolic compounds in extracts.

From the aforementioned it can be concluded that the antioxidant activity of the extracts of the investigated Fabaceae species depend upon: 1) plant species and varieties, solvent type and extraction method, 2) phenolic composition, 3) presence and type of quinolizidine type alkaloid, and/or 4) synergy of active compounds.

It can, therefore, be assumed that the antioxidant activity of analysed $P$. ramentacea extracts can be attributed to the presence of some alkaloids or compounds not analysed in this study, and it may be suggested that $P$. ramentacea can be used as a potential source of natural antioxidants but with its further exploration and determination of active compounds responsible for antioxidant efficacy.

Antibacterial and antifungal activities of $P$. ramentacea extracts Antibakterijska i antifungalna aktivnost ekstrakata $P$. ramentacea

Based on the available information on their traditional use, the plants are routinely investigated in order to isolate new compounds with antimicrobial activity (LIMA-FILHO and CORDEIRO 2014). The antibacterial activity of plants is due to the action of various chemical agents in the extracts: phenols, flavonoids, tannins, glycosides, saponins, terpenoids, alkaloids and anthocyanins (MORRIS et al. 1979, KAUR and MONDAL 2014). Many plant natural extracts are an important source of mycotoxic compounds because the plants have developed various defence mechanisms against fungal infections, including the synthesis of bioactive organic compounds, antifungal proteins and peptides, which depends on the plant species itself, the analysed tissue and the environmental factors (BROEKAERT et al. 1997, MORRISEY and OSBOURN 1999, WEBSTER et al. 2008). 
The results of the antibacterial and antifungal activity of methanol extracts of $P$. ramentacea for eight selected strains of microorganisms were presented for the first time in this study (Table 3). It can be noticed that analysed methanol extracts with the most prominent antioxidant activity (seeds) have moderate antimicrobial activity. The moderate antibacterial activity of methanol extracts, except for Staphylococcus epidermididis, was recorded against five selected bacterial strains, with a range of inhibition zones of 6.2 to $10.0 \mathrm{~mm}$. The analysed extracts had moderate antifungal activity against both selected fungi (range $6.5-8.1 \mathrm{~mm}$ inhibition zone). The extract of bark did not show any inhibitory effect on $A$. brasiliensis. Extracts with the lowest antioxidant activity showed stronger expressed inhibitory activity against $P$. aeruginosa and moderate activity against all other analysed microorganisms. The more pronounced antimicrobial activity, compared to other analysed extracts, showed $P$. ramentacea root extracts to the all selected microorganisms.

According to STEFANOVIC and COMIC (2011) and STEFANOVIĆ ET AL. (2012), various types of extracts of some Cytisus species are more efficient against certain pathogenic gram positive bacteria. STEFANOVIC and COMIC (2011) concluded that selective antibacterial characteristics and activity of extracts in some Cytisus species depended on both the bacterial strain and the type and concentration of the extract, with phenols and flavonoids having a significant role in their total biological activity.

Antibacterial and antifungal activity of various types of extracts, infusions and active substances of some Genista are tested against certain pathogenic strains of bacteria and fungi (ERDEMOGLU et al. 2009, LOGRADA et al. 2010, TOUBAL et al. 2011, BOUCHOUKA et al. 2012, KÜÇÜKBOYACl et al. 2012 and LOGRADA et al. 2012). Extracts, infusions, flavonoids and essential oils of some Genista showed strong antimicrobial activity against certain antibiotic resistant bacteria strains (LOGRADA et al. 2010, TOUBAL et al. 2011, BOUCHOUKA et al. 2012, LOGRADA et al. 2012), while alkaloid extracts showed significant antibacterial and antifungal activity against some strains of bacteria and fungi (ERDEMOGLU et al. 2009, KÜÇÜKBOYACl et al. 2012).

The Glycyrrhiza extracts possess moderate to strong antibacterial and antifungal activity against a variety of pathogens, most likely due to the presence of triterpenoid saponins, tannins, flavonoids and sugars (GUPTA et al. 2008, SULTANA et al. 2010, ASAN-OZUSAGLAM and KARAKOCA 2014).

It was noticed that the oils of Lupinus did not exhibit any antimicrobial activity, in comparison to the methanol extracts and alkaloids which showed moderate to strong antibacterial activity against certain pathogenic bacteria and poor to moderate antifungal activity against some fungi. This antimicrobial activity was associated with phenolic compounds, alkaloids and/or saponins and tannins (WINK, 1984, LAMPART-SZCZAPA et al. 2003, ERDEMOGLU et al. 2006, VILLA-RUANO et al. 2012, GWEE and CASE 2014, OHADOMA et al. 2014, HAMED and AYOUB 2015).

Also, the methanol extracts of Spartium junceum showed antibacterial activity only against certain grams of positive bacteria (HABIBATNI et al. 2016), while the 
essential oil of flowers has shown a certain degree of antimicrobial activity (ZHAO, 2014).

Given the measured antioxidant activity, the expressed antimicrobial activity, the determined total concentrations of certain phenolic compounds and the absence of correlation between them, as well as the results of previously published studies on $P$. ramentacea composition (KUŠTRAK and KUJUNDŽIĆ 1974, WINK and WITTE 1985, VEEN et al. 1992), it can be assumed that antibacterial and antifungal activity of analysed extracts is most likely due to the action of some of the quinolizidine type alkaloids or synergism of some active compounds.

\section{CONCLUSIONS - Zaključci}

The obtained results represent a significant contribution to the knowledge of the Balkan endemic species of Petteria ramentacea from the aspect of analysis of phenolic compounds in different plant parts and their antioxidative and antimicrobial activity against eight selected microorganisms. Methanol extracts of seeds and leaves had very high antioxidant activity, while extracts of other plant parts had fairly uniform and moderate activities. The methanol extracts showed moderate antifungal activity against Aspergillus brasiliensis and Candida albicans, and antibacterial activity against gram negative (Escherichia coli, Pseudomonas aeruginosa and Salmonella abony) and gram positive bacteria (Bacillus subtilis subsp. spizizenii and Staphylococcus aureus subsp. aureus), but not against Staphylococcus epidermididis. Since compounds present in small or very small amounts in methanol extracts may be involved in antimicrobial activity either directly or in a synergy with other bioactive compounds, and the obtained data in this study suggests the existence of moderate antioxidative and antimicrobial activity in all investigated $P$. ramentacea extracts, it would be desirable to continue to isolate and identify these bioactive compounds but also to investigate other constituents.

\section{ACKNOWLEDGMENTS - Zahvale}

The authors thank the Federal Ministry of Education and Science of Bosnia and Herzegovina [grant number 05-39-3087-22/16] for funding the research. 


\section{REFERENCES - Literatura}

ABOU-ZAID M, SCOTT IM. (2012): Pyrolysis bio-oils from temperate forests: fuels, phytochemicals and bioproducts. In: Bergeron C, Carrier DJ, Ramaswamy S. (eds), Biorefinery Co-products. Phytochemicals, primary metabolites and valueadded biomass processing, Wiley, Noida, India, pp. 323.

AIT-KACIAOURAHOUN K., FAZOUANE F, BENAYACHE S. (2015): Pharmacological potential of Cytisus triflorus 1'Hérit. Extracts as antioxidant and antiinflammatory agent. Der Pharmacia Lettre 7(5): 104-110.

AO C, LI A, ELZAAWELY A.A, XUAN D.T, TWATA S. (2008): Evaluation of antioxidant and antibacterial activities of Ficus microcarpa L. fill extract. Food Control 19: 940-948.

AOKI T, AKASHI T, AYABE SI. (2000): Flavonoids of leguminous plants: Structure, biological activity, and biosynthesis. Journal of Plant Research 113: 475-488.

BAUER AW, KIRBY WMM, SHERRIS JC, TURCK M. (1966): Antibiotic susceptibility testing by a standardized single disk method. American Journal of Clinical Pathology 36: 493-496.

BOUCHOUKA E, DJILANI A, BEKKOUCHE A. (2012): Antibacterial and antioxidant activities of three endemic plants from Algerian Sahara. Acta Scientiarum Polonorum. Technologia Alimentaria11(1): 61-65.

BROEKAERT WF, CAMMUE BPA, DE BOLLE MFC, THEVISSEN K, DE SAMBLANX GW,OSBORN RW. (1997): Antimicrobial peptides from plants. Critical Reviews in Plant Sciences 16: 297-323.

CROZIER A, JAGANATH IB, CLIFFORD MN. (2006): Phenols, polyphenols and tannins: An overview. In: Crozier A, Clifford MN, Ashihara H. (eds), Plant Secondary Metabolites: Occurrence, Structure and Role in the Human Diet, Blackwell Publishing Ltd, Oxford, UK.

ERDEMOGLU N, OZKAN S, DURAN A, TOSUN F. (2009): GC-MS analysis and antimicrobial activity of alkaloid extract from Genista vuralii. Pharmaceutical Biology 47(1): 81-85.

ERDEMOGLU N, OZKAN S, TOSUN F. (2006): Alkaloid profile and antimicrobial activity of Lupinus angustifolius L. alkaloid extract. Phytochemistry Review, DOI 10.1007/s11101-006-9055-8.

FAO (2006): Guidelines for soil description, Food and Agriculture Organization of the United Nations, Rome, Italy.

FERNANDES I, NAVE F, GONÇALVES R, DE FREITAS V, MATEUS N. (2012): On the bioavailability of flavanols and anthocyanins: Flavanol-anthocyanin dimers. Food Chemistry 135: 812-818.

FUKAREK P. (1949): O granicama prirodnog areala tilovine (Petteria ramentacea (Sieber) Presl.). Godišnjak biološkog instituta u Sarajevu II(1-2): 53-59.

FZAP (2013): Pedological map, Federal Institute of Agropedology of Federation of Bosnia and Herzegovina, www.agropedologija.gov.ba. 
GADZOVSKA S, MAURY S, DELAUNAY A, SPASENOSKI M, JOSEPH C, HAGĖGE D. (2007): Jasmonic acid elicitation of Hypericum perforatum L. cell suspensions and effects on the production of phenylpropanoids and naphtodianthrones. Plant Cell Tiss Organ Culture 89: 1-13.

GUETTAF S, ABIDLI N, KARICHE S, BELLEBCIR L, BOURICHE H. (2016): Phytochemical screening and antioxidant activity of aqueous extract of Genista saharae (Coss. \& Dur.) Der Pharmacia Lettre 8(1): 50-60.

GUPTA VK, FATIMA A, FARIDI U, NEGI AS, SHANKER K, KUMAR JK, RAHUJA N, LUQMAN S, SISODIA BS, SAIKIA D, DAROKAR MP, KHANUJA SPS. (2008): Antimicrobial potential of Glycyrrhiza glabra roots. Journal of Ethnopharmacology 116: 377-380.

GWEE J., CASE C. (2014): Antimicrobial properties of a traditional medicinal plant, Lupinus variicolor. SACNAS National Conference 16-18.10. Los Angeles, USA.

HABIBATNI S, MICELI N, GINESTRA G, MAAMERI Z, BISIGNANO C, CACCIOLA F, UTCZAS M, MONDELLO L, ANWAR S, BENAYACHE S, ZAMA D, BENAYACHE F, TAVIANO MF. (2016): Antioxidant and antibacterial activity of extract and phases from stems of Spartium junceum L. growing in Algeria. International Journal of phytomedicine 8(1): 37-46.

HAMED AOA, AYOUB SMH. (2015): Chemical composition and antimicrobial activity of Sudanese Lupinus termis L. root extracts. The Pharma Innovation Journal 4(5): 01-04.

HANGANU D, OLAH N, BENEDEC D, MOCAN A, CRISAN G, VLASE L, POPICA I, ONIGA I. (2016):Comparative polyphenolic content and antioxidant activities of Genista tinctoria L. and Genistella sagittalis (L.) Gams (Fabaceae). Pakistan Journal of Pharmaceutical Sciences 29(1, Suppl): 301-307.

HERAVI MM, RODI S, ARDALAN P. (2013): Study of antioxidant and free radical scavenging activities of Cotoneaster medicus and Glycyrrhiza glabra plants. Journal of Chemical Health Risks 3(2): 27-34, 2013.

HUANG D, OU B, PRIOR RL. (2005): The chemistry behind antioxidant capacity assays. Journal of Agriculture and Food Chemistry 53: 1841-1856.

ISO 10390. (2005): www.iso.org/standard/40879.html.

ISO 10693. (1994): www.iso.org/standard/18781.html.

IUSS WORKING GROUP WRB. (2007): World Reference Base for Soil Resources 2006. First Update 2007. in: Bundesanstalt für Geowissenschaften und Rohstoffe (Ed.), Hannover, pp. 128.

KÄHKÖNEN MP, HOPIA AI, VUORELA HJ, RAUHA J, PIHLAJA K, KUJALA TS, HEINONEN M. (1999): Antioxidant activity of plant extracts containing phenolic compounds. Journal of Agricultural and Food Chemistry 47: 3954-3962.

KAUR S, MONDAL P. (2014): Study of total phenolic and flavonoid content, antioxidant activity and antimicrobial properties of medicinal plants. Journal of Microbiology \& Experimentation 1(1): 00005, DOI: 10.15406/jmen.2014.01.00005. 
KÜÇÜKBOYACI N, ÖZKAN S, TOSUN F. (2012): Gas chromatographic determination of quinolizidine alkaloids in Genista sandrasica and their antimicrobial activity. Records of Natural Products 6: 171-174.

KUŠTRAK D, KUJUNDŽić N. (1974): Tilovina-ukras imotskog kamenjara. Priroda LXIII (3): 65-68.

LAMPART-SZCZAPA E, SIGER A, TROJANOWSKA K, NOGALA-KALUCKA M, MALECKA M, PACHOLEK B. (2003): Chemical composition and antibacterial activities of lupin seeds extracts. Die Nahrung 47(5): 286-290.

LIMA-FILHO JV, CORDEIRO RA. (2014): In vitro and in vivo antibacterial and antifungal screening of natural plant products: prospective standardization of basic methods. iN: Albuquerque UP. et al. (eds.), Methods and Techniques in Ethnobiology and Ethnoecology, Springer Protocols Handbooks, DOI 10.1007/978-1-4614-8636-7 17.

LOGRADA T, CHAKER AN, CHALCCHAT JC, RAMDANI M, SILINI H, FIGUEREDO G, CHALARDE P. (2010): Chemical composition and antimicrobial activity of essential oils of Genista ulicina and G. vepres. Natural Product Communications 5(5): 835-838.

LOGRADA T, RAMDANI M, FIGUEREDO G, CHALCHAT J.C, CHALARD P. (2012): Essential oil composition and antimicrobial activity of Genista microcephala Coss. et Dur. International Journal of Medicinal and Aromatic Plants 2(1): 75-79.

LUIS A, DOMINGUES F, GIL C, DUARTE AP. (2009): Antioxidant activity of extracts of Portuguese shrubs: Pterospartum tridentatum, Cytisus scoparius and Erica spp.. Journal of Medicinal Plants Research 3(11): 886-893.

MADRID AM, ESPINOZA LJ, MELLADO MA, OSORIO ME, MONTENEGRO IJ, JARA CE. (2012): Evaluation of the antioxidant capacity of Psoralea glandulosa L. (Fabaceae) extracts. Journal of the Chilean Chemical Society 57(3): 1328-1332.

MEDA A, LAMIEN CE, ROMITO M, MILLOGO J, NACOULMA OG. (2005): Determination of the total phenolic, flavonoid and proline contents in Burkina Fasan Honey, as well as their radical scavenging activity. Food Chemistry 91(3): 571-577.

MORRIS J, KHETTRY A, SEITZ EW. (1979): Antimicrobial activity of aroma chemicals and essential oils. Journal of the American Oil Chemists' Society 56: 595-603.

MORRISEY JP, OSBOURN A. (1999): Fungal resistance to plant antibiotics as a mechanism of pathogenesis. Microbiology and Molecular Biology Reviews 63: 708-724.

MUNSELL COLOR. (1994): Munsell Soil Color Charts. New Windsor.

NADAŽDIN M, ĆURIĆ R. (1966): Rasprostranjenje, ekologija i ekonomski značaj zanovijeti (Tilovine) Petteria ramentacea u Hercegovini. Šumarski list 5-6: 286292.

NAGHILOO S, MOVAFEGHI A, DELAZAR A, NAZEMIYEH H, ASNAASHARI S, DADPOUR MR. (2012): Ontogenetic variation of total phenolics and antioxidant 
activity in roots, leaves and flowers of Astragalus compactus Lam. (Fabaceae). Bioimpacts 2(2): 105-109.

OHADOMA SC, NNATUANYA I, AMAZU LU, OKOLO CE. (2014): Antimicrobial activity of the leaf extract and fractions of Lupinus arboreus. Journal of Medicinal Plant Research 8(8): 386-391.

OOMAH BD, TIGER N, OLSON M, BALASUBRAMANIAN P. (2006): Phenolics and antioxidative activities in narrow-leafed lupins (Lupinus angustifolius L.). Plant Foods for Human Nutrition 61(2): 91-97.

ORDOÑEZ A, GOMEZ J, VATTUONE M, ISLA M. (2006): Antioxidant activities of Sechium edule (Jacq.) Swart extracts. Food Chemistry 97: 452-458.

OREOPOULOU V. (2003): Extraction of natural antioxidants. In: Tzia C, Liadakis G. (eds), Extraction optimization in food engineering, Marcel Dekker Inc., New York, pp. 329-346.

ORHAN IE, TOSUN F, TAMER U, DURAN A, ALAN B, KÖK AF. (2010): Quantification of genistein and daidzein in two endemic Genista species and their antioxidant activity. Journal of the Serbian Chemical Society 76(1): 35-42.

PEREIRA OR, SILVA AM, DOMINGUES MR, CARDOSO SM. (2012): Identification of phenolic constituents of Cytisus multiflorus. Food Chemistry 131(2): 652-659.

ROBARDS K, PRENZLER PD, TUCKER G, SWATSITANG P, GLOVER W. (1999): Phenolic compounds and their role in oxidative processes in fruits. Food Chemistry 66: 401-436.

SANCHEZ-MORENO C, LARRAURI JA, SAURA-CALIXTO F. (1999): Free radical scavenging capacity and inhibition of lipid oxidation of wines, grape juices and related polyphenolic constituents. Food Research International 32: 407-412.

SINGELTON VR, ORTHIFER R, LAMUELA-RAVENTOS RM. (1999): Analysis of total phenols and other oxidation substrates and antioxidants by means of FolinCiocalteu reagent. Methods in Enzymology 299: 152-178.

SPIRIDON I, COLCERU S, ANGHEL N, TEACA CA, BODIRLAU R, ARMATU A. (2011): Antioxidant capacity and total phenolic contents od oregano (Origanum vulgare), lavender (Lavandula angustifolia) and lemon balm (Melissa officinalis) from Romania. Natural Product Research 25(17): 1657-1661.

STEFANOVIC O, COMIC LJ. (2011): Inhibitory effect of Cytisus nigricans L. and Cytisus capitatus Scop. on growth of bacteria. African Journal of Microbiology Research 5(27): 4725-4730.

STEFANOVIĆ O, RADOJEVIĆ I, VASIĆ S, ČOMIĆ LJ. (2012): Antibacterial activity of naturally occurring compounds from selected plants. In: Bobbarala V. (ed), Antimicrobial Agents. InTech, ISBN 978-953-51-0723-1, DOI: 10.5772/1867: 124.

SULTANA S, HAQUE A, HAMID K, URMI KF, ROY S. (2010): Antimicrobial, cytotoxic and antioxidant activity of methanolic extract of Glycyrrhiza glabra. Agriculture and Biology Journal of North America 1(5): 957-960.

TALA VRS, DA SILVA VC, RODRIGUES CM, NKENGFACK AE, DOS SANTOS LC, VILEGAS W. (2013): Characterization of proanthocyanidins from Parkia 
biglobosa (Jacq.) G. Don. (Fabaceae) by flow injection analysis-electrospray ionization ion trap tandem mass spectrometry and liquid chromatography/electrospray ionization mass spectrometry. Molecules 18: 28032820.

TOUBAL O, DJAHOUDI A, BOUZABATA A. (2011): Preliminary studies and antimicrobial evaluation of the aerial parts of Genista numidica ssp. numidica. Journal of Life Sciences 5(11): 954.

VEEN G, GÜNTHER S, GREINWALD R, BACHMANN P, WITTE L, KUŠTRAK D, CZYGAN F. (1992): Quinolizidine alkaloids in Petteria ramentacea. Phytochemistry 31(10): 3487-3490.

VERMERRIS W, NICHOLSON R. (2008): Phenolic compound biochemistry. Springer Science+Business Media B.V.

VILLA-RUANO N, PACHECO-HERNÁNDEZ Y, RUBIO-ROSAS E, RUIZ-GONZÁLEZ N, CRUZ-DURAN R, LOZOYA-GLORIA E, ZURITA-VÁSQUEZ G, FRANCOMONSREAL J. (2012): Alkaloid profile, antibacterial and allelopathic activities of Lupinus jaimehintoniana B.L. Turner (Fabaceae). Archives of Biological Science Belgrade 64(3): 1065-1.

WALKLEY A, BLACK IA. (1934): An examination of Degtjareff method for determining soil organic matter, and proposed modification of the chromic acid tritation method. Soil Sci. 37: 29-38.

WANG S, CLEMENTS J. (2008): Antioxidant activites of lupin seed. Proceedings $12^{\text {th }}$ International Lupin conference, Fremantle, Western Australia, 14-18.09: 546551.

WEBSTER D, TASCHEREAU P, BELLAND RJ, SAND C, RENNIE RP. (2008): Antifungal activity of medicinal plant extracts. Preliminary screening studies. Journal of Ethnopharmacology 115: 140-146.

WETTSTEIN D, JENDE-STRID B, AHRENST-LARSEN B, SORENSESN JA. (1977): Biochemical mutant in barley renders chemical stabilization of beer superfluous. Carlsberg Research Communications 42(5): 341-351.

WINK M, WITTE L. (1985): Quinolizidine alkaloids in Petteria ramentacea and the infesting aphids, Aphiscytisorum. Phytochemistry 24(11): 2567-2568.

WINK M. (1984): Chemical defense of Leguminosae. Are quinolizidine alkaloids part of the antimicrobial defense system of Lupins? Zeitschrift für Naturforschung 39c: 548-552.

WINK M. (2013): Evolution of secondary metabolites in legumes (Fabaceae). South African Journal of Botany, 89: 164-175.

WOLFE K, WU X, LIU HR. (2003): Antioxidant activity of apple peels. Journal of Agricultural and Food Chemistry 51: 609-614.

WOYDIŁO A, OSZMIAŃSKI J, CZEMERYS R. (2007): Antioxidant activity and phenolic compounds in 32 selected herbs. Food Chemistry 105: 940-949. 
YANG L, WEN K-S, RUAN X, ZHAO Y-X, WEI F, WANG Q. (2018): Response of plant secondary metabolites to environmental factors. Molecules 23: 762; doi:10.3390/molecules23040762www.mdpi.com/journal/molecules.

ZHAO MT. (2014): Caracterisations chimiques et biologiques d'extraits de plantes aromatiques et medicinales oubliees ou sousutilisees de Midi-Pyrenees (France) et Chongqing (Chine). Doctorat de L'université de Toulouse, Institut National Polytechnique de Toulouse, pp. 37-39.

ZHENG W, WANG SY. (2001): Antioxidant activity and phenolic compounds in selected herbs. Journal of Agricultural and Food Chemistry 49(11): 5165-70.

\section{SAŽETAK}

Dobiveni rezultati u ovoj studiji predstavljaju značajan doprinos poznavanju balkanske endemične vrste Petteria ramentacea s aspekta prisutnosti fenolnih jedinjenja $u$ različitim biljnim dijelovima te njihove antioksidacijske i antimikrobne aktivnosti protiv osam odabranih mikroorganizama. Metanolni ekstrakti sjemena i lišća imali su vrlo visoku antioksidativnu aktivnost, a ekstrakti ostalih biljnih dijelova imali su prilično ujednačene i umjerene aktivnosti. Metanolni ekstrakti pokazali su umjereno antifungalno djelovanje protiv Aspergillus brasiliensis i Candida albicans, te antibakterijsko djelovanje protiv gram negativnih (Escherichia coli, Pseudomonas aeruginosa i Salmonella abony) i gram pozitivnih bakterija (Bacillus subtilis subsp. spizizenii i Staphylococcus aureus subsp. aureus), ali ne i protiv Staphylococcus epidermididis. S obzirom da jedinjenja prisutna u malim ili vrlo malim količinama u metanolnim ekstraktima mogu biti uključena $u$ antimikrobnu aktivnost te da dobiveni podaci u ovoj studiji upućuju na postojanje umjerene antioksidacijske i antimikrobne aktivnosti u svim ispitivanim ekstraktima $P$. ramentacea bilo bi poželjno uraditi njihovu izolaciju i identificirati te bioaktivne spojeve, ali i analizirati ostale sastojke.

Corresponding author: Fatima Pustahija; Faculty of Forestry University of Sarajevo; Zagrebačka 20, 71000 Sarajevo, Bosnia and Herzegovina; e-mail address: f.pustahija@sfsa.unsa.ba 